http://dx.doi.org/10.18778/1509-877X.2018.01.01

Artykuły

Stefan Babiarz ${ }^{\star}$

\title{
GLOSA DO WYROKÓW NSA Z DNIA 6 CZERWCA 2018 R., SYGN. II FSK 1525/16 I II FSK 1526/16
}

\begin{abstract}
Streszczenie. Umowa darowizny może zostać obciążona poleceniem (art. 893 k.c.). Istota polecenia nie jest jednolita, albowiem w jego treści mieści się też możliwość ustanowienia zobowiązania do świadczenia określonej kwoty pieniężnej zgodnie z art. $393 \$ 1$ k.c. W takim przypadku wartością przedmiotu darowizny powinna być różnica między kwotą darowizny otrzymaną przez obdarowanego a kwotą świadczenia dla osoby trzeciej (art. $888 \$ 1$ w zw. z art. 893 k.c.). Polecenie darczyńcy skierowane do obdarowanego jest ciężarem darowizny i tym samym podlega odliczeniu od jej wartości. Z kolei świadczenie nieodpłatne zdziałane przez darczyńcę wobec tej osoby trzeciej nie jest obciążone ciężarem, z tym jednak, że osoba, która otrzymała to świadczenie, podlegałaby opodatkowaniu podatkiem od spadków i darowizn na ogólnych zasadach (art. 1 ust. 1 pkt 2, art. 6 ust. 1 pkt 4, art. 9 ust. 1 pkt 1 i art. 14 ust. 3 pkt 1 u.p.s.d.). Wartość tego świadczenia nie jest długiem ani ciężarem dla osoby obdarowanej, zostało ono bowiem zdziałane kosztem majątku darczyńcy, a nie obdarowanego (art. $888 \$ 1$ k.c., art. 7 ust. 1 i 2 u.p.s.d.).
\end{abstract}

Słowa kluczowe: darowizna, polecenie darczyńcy, świadczenie na rzecz osoby trzeciej, długi i ciężary umowy darowizny i polecenia darczyńcy

1. W sprawach zakończonych wskazanymi w tytule wyrokami zagadnieniem istotnym do rozstrzygnięcia przez Naczelny Sąd Administracyjny (NSA) była wykładnia i zastosowanie w sprawie art. 7 ust. 1 i 2 Ustawy z dnia 28 lipca 1983 r. o podatku od spadków i darowizn² (dalej: u.p.s.d.). $\mathrm{W}$ istocie rzeczy zagadnienie to sprowadzało się, mówiąc w uproszczeniu,

* Sędzia Naczelnego Sądu Administracyjnego, e-mail: babiarzstefan@gmail.com

${ }^{1}$ Wyrok dostępny w Centralnej Bazie Orzeczeń Sądów Administracyjnych (CBOSA).

${ }^{2}$ Dz.U. z 2018 r., poz. 644. 
do rozstrzygnięcia, czy polecenie darczyńcy nakładające na obdarowanego wykonanie określonego obowiązku majątkowego z przedmiotu darowizny będzie dla tego obdarowanego długiem tej darowizny czy nie.

2. Stan faktyczny spraw przedstawiał się następująco: darczyńcy byli małżonkami i ze środków stanowiących ich majątek wspólny darowali córce kwotę 120000 zł. Umowa darowizny została zawarta w dniu 25 lipca 2010 r. i w dniu 26 lipca 2010 r. wykonana przez przelew środków pieniężnych na rachunek obdarowanej. Darowizna została zdziałana do majątku odrębnego obdarowanej, przy czym obdarowana w chwili darowizny była zamężna.

W umowie darowizny darczyńcy zobowiązali obdarowaną do nabycia za przedmiot darowizny konkretnie oznaczoną nieruchomość. Z umowy darowizny wynikało, że realizacja obowiązku przeznaczenia przedmiotu darowizny na wskazany w umowie cel ma nastąpić w następujący sposób:

$\$ 3.1 .1$ - część sumy pieniężnej stanowiącej przedmiot darowizny w wysokości 65000 zł zostanie przez obdarowaną przekazana sprzedającej nieruchomość - XY,

- pozostała część sumy pieniężnej stanowiącej przedmiot darowizny w wysokości 55000 zł zostanie przez obdarowaną przekazana mężowi obdarowanej - TZ.

Strony w pkt $2 \$ 3$ umowy stwierdziły, że postanowienia zawarte w pkt 1 stanowią polecenie w rozumieniu art. 893 Kodeksu cywilnego ${ }^{3}$ (dalej: k.c.). Wykonanie tej umowy w zakresie poleceń nastąpiło w ten sposób, że w dniu 26 lipca 2010 r. obdarowana przelewem przekazała na rachunek męża kwotę 55000 zł, zaś w dniu 27 lipca 2010 r. także przelewem przekazała sprzedawcy nieruchomości (TZ) kwotę 65000 zł. Umowa przeniesienia własności nieruchomości na rzecz obdarowanej i jej męża nastąpiła w dniu 27 lipca 2010 r. Okoliczność, że nieruchomość ta ma zostać nabyta przez obdarowaną i jej męża, została wskazana również w umowie darowizny (\$1 pkt 3).

Obdarowana w związku z uchybieniem terminu do złożenia zgłoszenia zwolnienia podmiotowego $\mathrm{z}$ art. 4a u.p.s.d. (druk SDZ-2) nie mogła skorzystać z tego zwolnienia. Prawdopodobnie z takiego zwolnienia $\mathrm{z}$ tych samych powodów nie skorzystał także mąż obdarowanej, który otrzymał w wyniku polecenia darczyńcy (art. 1 ust. 1 pkt 2 u.p.s.d.) kwotę 55000 zł.

\footnotetext{
${ }^{3}$ Tekst jedn. Dz.U. z 2019 r., poz. 1145.
} 
W związku ze wszczętymi w tych sprawach postępowaniami podatkowymi w stosunku do obdarowanej z tytułu dwóch darowizn od matki i od ojca, po ponownym rozpoznaniu sprawy organ podatkowy pierwszej instancji ustalił obdarowanej w każdej z decyzji zobowiązania podatkowe w kwotach po 984 zł, przyjmując, że wartość darowizny wynosi w każdej ze spraw po $60000 \mathrm{zl}$, a dług po $27500 \mathrm{zł}^{4}$. Nie uznał za dług kwot po $32500 \mathrm{zł}$ z tytułu polecenia darczyńców nałożonego na obdarowaną, przedmiotem którego było nabycie własności nieruchomości. Stanowisko to podzielił także organ odwoławczy, który decyzjami z dnia 8 lipca 2015 r. utrzymał w mocy decyzje organu podatkowego pierwszej instancji. Skargi obdarowanej Wojewódzki Sąd Administracyjny (WSA) w P. oddalił, podzielając stanowisko obu organów podatkowych. Sąd wskazał, że „nie sposób przyznać racji skarżącej, że wolą ustawodawcy było, aby każde polecenie darowizny w rozumieniu prawa cywilnego, o ile zostało wykonane, zmniejszało podstawę opodatkowania podatkiem od spadków i darowizn". Zdaniem sądu taka wykładnia art. 7 ust. 1 i 2 u.p.s.d. byłaby sprzeczna nie tylko z językowym brzmieniem przepisu, ale i jego celem. Sąd podkreślił, że „czysta wartość jest [...] wartością, która stanowi przysporzenie w majątku osoby obdarowanej (spadkobiercy) [...] a wykonanie przez skarżącą polecenia nie wpłynęło na zmniejszenie przysporzenia w jej majątku jako osoby obdarowanej. Zmianie uległa tylko forma majątku”. Ponadto „przepis art. 7 ust. 2 u.p.s.d. mówi, że polecenie jest ciężarem spadku, jeżeli obdarowany został obciążony obowiązkiem jego wykonania”. Istotne znaczenie przy interpretacji tego zwrotu ma słowo „obciążony”, co zdaniem sądu oznacza, że wykonanie polecenia powinno wiązać się z ciężarem po stronie obdarowanego, tzn. że powinno być wykonane w taki sposób, by wartość nabytych rzeczy lub praw uległa umniejszeniu. Gdyby ustawodawca chciał, żeby każde polecenie zmniejszało podstawę opodatkowania w podatku od

${ }^{4} \mathrm{~W}$ glosie dla jaśniejszego zrozumienia stanu faktycznego pomija się fakt, że w rzeczywistości wobec obdarowanej toczyły się dwie sprawy podatkowe. Obdarowana otrzymała bowiem dwie darowizny, a zatem dwukrotnie nabyła własność rzeczy, z tym że to, czy pieniądze są rzeczą, jest kwestią sporną. Zob. J. Ignatowicz, Komentarz do art. 45, [w:] Kodeks cywilny. Komentarz, t. 1, red. Z. Rosiak, WP, Warszawa 1972, s. 124-125; E. Gniewek, Komentarz do art. 45, [w:] Kodeks cywilny. Komentarz, t. 1, red. E. Gniewek, C.H. Beck, Warszawa 2004, s. 167; W.J. Katner, Komentarz do art. 45 k.c. lit. E, [w:] Kodeks cywilny. Komentarz. Czesść ogólna, red. P. Księżak, M. Pyziak-Szafnicka, LEX/el., Warszawa 2014; wyrok SN z dnia 4 grudnia 1998 r., sygn. III CKN 49/98, LEX nr 35536. Przyjąć jednak należy, że jest to rzecz sui generis. 
spadków i darowizn, to postanowiłby o tym wprost w przepisie, stwierdzając, że „ciężarem darowizny jest wykonane polecenie”.

$\mathrm{Na}$ skutek skarg kasacyjnych obdarowanej (skarżącej) Naczelny Sąd Administracyjny wyrokami z dnia 6 czerwca 2018 r. uchylił zarówno zaskarżone wyroki WSA w P., jak i zaskarżone decyzje Dyrektora Izby Skarbowej. Zgodnie z poglądem NSA sąd pierwszej instancji przyjął, że „Z treści art. 7 ust. 2 w związku z art. 7 ust. 1 u.p.s.d. płynie wniosek, iż polecenie zmniejsza podstawę opodatkowania tylko wtedy, gdy obowiązek jego wykonania obciąża obdarowanego, co oznacza, że polecenie musi zostać dokonane kosztem majątku obdarowanego i umniejszyć wartość nabytych w drodze darowizny rzeczy i praw majątkowych”. Wedle tego sądu „polecenie może być nałożone na obdarowanego tak po zawarciu umowy darowizny, jak i po jej wykonaniu. Nie ma to jednak istotnego znaczenia dla oceny ważności umowy darowizny, a osobą, na rzecz której umowa darowizny przewiduje wykonanie polecenia, może być: osoba trzecia, sam darczyńca oraz obdarowany". Ponadto ustawodawca w art. 7 ust. 1 i 2 u.p.s.d. nie wprowadził przy tym warunku, że beneficjentem polecenia może być jedynie osoba trzecia, ewentualnie darczyńca. Przepisy te mają zatem zastosowanie także w sytuacji, w której beneficjentem polecenia jest sam obdarowany. Zauważył przy tym, że słowo „obciążony”, o którym mowa w art. 7 ust. 2 u.p.s.d., odnosi się do obowiązku, którego wykonaniem został obciążony obdarowany, a wartość obciążenia $\mathrm{z}$ tego tytułu stanowi ciężar spadku (zapisu) lub darowizny i odnosi się do wykonania polecenia bez zróżnicowania ze względu na charakter i rodzaj tegoż polecenia.

3. Oba wyroki, co warto podkreślić, zasługują na glosowanie z kilku powodów: po pierwsze, ze względu na problemy w nich poruszane, po drugie, ze względu na niepełną argumentację Naczelnego Sądu Administracyjnego i po trzecie, choćby dlatego, że w prasie po ogłoszeniu wyroków ukazały się krytyczne uwagi na ich temat ${ }^{5}$. Już na wstępie trzeba podkreślić, że oba glosowane wyroki są trafne. Jednakże rozważania na temat skutków podatkowych polecenia darczyńcy należało rozpocząć od zagadnień cywilnoprawnych.

Otóż nie wdając się - co wynika z objętości glosy - w rozwiązanie problemu teoretycznoprawnego: zasada, reguła czy dyrektywa interpretacyjna ${ }^{6}$,

${ }^{5}$ Zob. Darowizna z poleceniem bez podatku - przełomowy wyrok NSA, „Rzeczpospolita” 7.06.2018; Koniec podatku od spadków i darowizn. Fiskus straci wpływ z podatku od spadków i darowizn, „Dziennik Gazeta Prawna” 7.06.2018.

${ }^{6}$ Zob. na ten temat np. M. Korzycka-Zirk, Teorie zasad prawa a zasada proporcjonalności, LexisNexis, Warszawa 2012 s. 13-27; P. Tuleja, Zasady konstytucyjne, 
wskazać należy, w pewnym uproszczeniu, że zarówno zasady, jak i reguły są normami prawnymi o większym lub mniejszym stopniu ogólności. To oznacza, że tzw. zasada respektowania w prawie podatkowym pojęć przejętych $\mathrm{z}$ innych gałęzi prawa, $\mathrm{w}$ tym $\mathrm{z}$ prawa cywilnego, $\mathrm{w}$ istocie zasadą $\mathrm{w}$ powyższym rozumieniu nie jest. Jest jednak chyba zasadą opisową, czyli zasadą języka prawniczego. Ma ona następczy charakter w stosunku do tekstu prawnego i analiza tekstu prawnego doprowadziła do jej wyeksponowania ${ }^{8}$. W tym więc znaczeniu można o niej mówić także jako o dyrektywie interpretacyjnej pozwalającej uniknąć niejednoznaczności i tym samym pomijania zasad w procesie wykładni. Dlatego też w literaturze ${ }^{9}$ wskazuje się, że „zasada respektowania pojęć przyjętych $\mathrm{z}$ innych dziedzin prawa” powinna stać się jedną z zasad ogólnych nowej Ordynacji podatkowej.

W związku z tym wskazuje się, że „użyte w przepisach prawa podatkowego pojęcia, mające utrwalone znaczenie w innych dziedzinach praw, mają to samo znaczenie $\mathrm{w}$ prawie podatkowym, chyba że przepis prawa podatkowego inaczej stanowi"10. Jest to stanowcze domniemanie interpretacyjne. Jednak podkreśla się ${ }^{11}$, że „ze względu na niebezpieczeństwo z tym związane (czyli z przyjęciem tej dyrektywy interpretacyjnej) sformułować należy dwa postulaty nawiązujące do podstawowych reguł techniki legislacyjnej [...]:

- ustawodawca, tworząc przepisy prawa podatkowego, powinien posługiwać się terminami i zwrotami występującymi na gruncie innych gałęzi, w innym niż na gruncie tych gałęzi znaczeniu tylko wówczas, gdy

[w:] Konstytucjonalizacja zasad i instytucji ustrojowych, red. P. Sarnecki, Wydawnictwo Sejmowe, Warszawa 1997, s. 12; M. Zieliński, Konstytucyjne zasady prawa, [w:] Charakter i struktura norm konstytucji, red. J. Trzciński, Wydawnictwo Sejmowe, Warszawa 1997, s. 59.

${ }^{7}$ R. Alexy, Balancing, Constitutional Review and Representation, Oxford University Press - New York University School of Law 2005, T-CON, vol. 3, no. 4, s. 572; idem, Theory of Constitutional Rights, Oxford University Press, New York 2002, s. 45-46.

${ }^{8}$ M. Korzycka-Zirk, Teorie zasad prawa..., s. 17.

${ }^{9}$ Zob. B. Brzeziński, W. Nykiel, Zasady ogólne prawa podatkowego, „Przegląd Podatkowy” 2002, nr 3, s. 9-11; Projekt przepisów ogólnych Ordynacji podatkowej, opracowany przez zespół roboczy Centrum Dokumentacji $i$ Studiów Podatkowych $w$ Łodzi w składzie: prof. dr hab. B. Brzeziński, prof. dr hab. W. Chróścielewski, dr H. Dzwonkowski, dr hab. M. Kalinowski, dr M. Masternak, prof. dr hab. W. Nykiel (przewodniczacy) i dr A. Olesińska, „Kwartalnik Prawa Podatkowego” 2001, nr 3-4, s. 115-121; B. Brzeziński, Podstawy wykładni prawa podatkowego, ODDK, Gdańsk 2008, s. 18-19.

${ }^{10}$ B. Brzeziński, W. Nykiel, Zasady ogólne..., s. 10.

${ }^{11}$ Ibidem. 
posłużenie się tymi zwrotami, terminami w znaczeniu nadanym im przez unormowania tych gałęzi nie jest możliwe,

- nowe znaczenie powinno być nadane terminom i zwrotom wyraźnie tam przejętym $\mathrm{z}$ innych gałęzi, niż powinno ono wynikać jedynie $\mathrm{z}$ kontekstu, w jakim ich użyto".

Są to istotne reguły interpretacyjne. Stąd już na wstępie należy zauważyć, że w rozważaniach chodzi o opodatkowanie nabycia własności rzeczy i praw majątkowych (art. 1 ust. 1 pkt 1-6 u.p.s.d.) na skutek czynności prawa cywilnego. Przedmiotami opodatkowania są tu nabycie własności rzeczy i praw majątkowych tytułem np. dziedziczenia, darowizny czy polecenia darczyńcy. Ustawodawca w art. 1 ust. 1 u.p.s.d. wyraźnie zawęża przedmiot opodatkowania do ściśle wskazanych tytułów nabycia własności rzeczy lub praw majątkowych przez osoby fizyczne. Co charakterystyczne, wiąże ten przedmiot nabycia ze ściśle określonymi czynnościami prawa cywilnego (w przypadku określonym w art. 1 ust. 2 u.p.s.d. także z czynnościami $\mathrm{z}$ innych dziedzin prawa). W konkretnym przypadku w rozpatrywanych sprawach chodziło o takie nabycie, jak tytułem darowizny czy polecenia darczyńcy. Ustawodawca w ustawie o podatku od spadków i darowizn nie nadał określeniu „darowizna” czy „polecenie darczyńcy” innego znaczenia niż takie, jakie występuje w art. 888 i 893 Kodeksu cywilnego. Należy podkreślić, że użycie tych zwrotów w innym znaczeniu nie byłoby możliwe, skoro opodatkowaniu podlegają określone akty nabycia własności rzeczy i praw majątkowych, które zostały wykreowane w prawie cywilnym. Podobnie zresztą rzecz się przedstawiała na gruncie art. 1 ust. 1 poprzednio obowiązującej Ustawy z dnia 19 grudnia 1975 r. o podatku od spadków i darowizn ${ }^{12}$. Co więcej, w art. 1 ust. 1 u.p.s.d. chodzi o opodatkowanie czynności tak nazwanych w prawie cywilnym, a nie o opodatkowanie takich, które są tylko do nich podobne ${ }^{13}$. W zakresie określenia przedmiotu opodatkowania podatkiem od spadków i darowizn ze względu na przedmiot opodatkowania nie jest możliwe posługiwanie się wskazanymi w art. 1 ust. 1 u.p.s.d. określeniami w znaczeniu innym niż cywilnoprawne $-\mathrm{z}$ dwóch powodów. Po pierwsze, mogłoby wówczas dojść do złamania zasady z art. 2 ust. 1 pkt 3 Ustawy z dnia 26 lipca 1991 r. o podatku

12 Dz.U. z 1975 r., Nr 45, poz. 228.

${ }^{13}$ Przykładowo, nie podlega opodatkowaniu jako darowizna czynność współkredytowania zakupu mieszkania, zob. Pismo z dnia 24 maja 2011 r. - interpretacja indywidualna DIS w Warszawie, sygn. IPPB2/436-93/11-2/AF. 
dochodowym od osób fizycznych ${ }^{14}$ dotyczącej poddania podatkowi od spadków i darowizn tych czynności, które powinny podlegać podatkowi dochodowemu od osób fizycznych, a po drugie, dochodziłoby wówczas do wyprowadzenia obowiązku podatkowego $\mathrm{z}$ wykładni przepisów prawa ${ }^{15}$. W związku z tym, że jak wspomniano wyżej, odmienne niż przejęte z innej dziedziny prawa dane określenie nie powinno wynikać z kontekstu, w jakim go użyto. Określenie „darowizna” użyte w art. 1 ust. 1, w art. 4 ust. 1 pkt 6 , w art. 4 a ust. 1 pkt 2 czy w art. 6 ust. 1 pkt 4 u.p.s.d. dowodzi, że ustawodawca użył go w znaczeniu wynikającym $\mathrm{z}$ art. 888 k.c. Wskazuje na to wyraźnie art. 6 ust. 1 pkt 4 u.p.s.d. nawiązujący do treści art. $890 \$ 1$ k.c., z którego wynika, że oświadczenie darczyńcy powinno być złożone w formie aktu notarialnego. Jednakże umowa darowizny zawarta bez zachowania tej formy staje się ważna, jeżeli przyrzeczone świadczenie zostało spełnione. Przepis art. 6 ust. 1 pkt 4 u.p.s.d. wskazujący na moment powstania obowiązku podatkowego jest więc systemowo spójny z art. $890 \$ 1$ k.c. Nie powinno więc być też wątpliwości, że polecenie darczyńcy, o którym mowa w art. 1 ust. 1 pkt 2 u.p.s.d., to polecenie, o którym mowa w art. 893 k.c. Poza tym w $\$ 9$ Zasad techniki prawodawczej ${ }^{16}$ wskazuje się na powinność posługiwania się określeniami, które zostały użyte w ustawie podstawowej dla danej dziedziny spraw. Język prawny jest tylko swoistą odmianą języka etnicznego i sformułowane w języku prawnym definicje w ustawie podstawowej powinny być respektowane co do zasady w innych ustawach.

4. W komentowanych wyrokach zatem zarówno określenie „darowizna”, jak i „polecenie” powinny być rozumiane w znaczeniu nadanym im przez art. 888 k.c. („Przez umowę darowizny darczyńca zobowiązuje się do bezpłatnego świadczenia na rzecz obdarowanego kosztem swojego majątku") i art. 893 k.c. („Darczyńca może włożyć na obdarowanego obowiązek oznaczonego działania lub zaniechania, nie czyniąc nikogo wierzycielem (polecenie)"). W rozpoznawanych przez Naczelny Sąd Administracyjny sprawach darowizny dokonali małżonkowie w trakcie trwania wspólności ustawowej.

${ }^{14}$ Dz.U. z 2018 r., poz. 2002 ze zm.

15 Zob. np. glosa krytyczna A. Bartosiewicza i A. Kubackiego do uchwały 7 sędziów NSA z dnia 28 maja 2007 r., I FPS 5/06, „Glosa” 2008, nr 2, s. 109-117; B. Brzeziński, M. Zirk-Sadowski, Specyfika wykładni prawa podatkowego, [w:] Zagadnienia ogólne prawa podatkowego, red. W. Nykiel, M. Wilk, Fundacja Centrum Dokumentacji i Studiów Podatkowych (CDISP), Łódź 2014, s. 63-77.

${ }^{16}$ Rozporządzenie Rady Ministrów z dnia 20 czerwca 2002 r. w sprawie „Zasad techniki prawodawczej", Dz.U. z 2002 r., Nr 100, poz. 908 ze zm. 
Zgodnie $\mathrm{z}$ art. $37 \$ 1$ pkt 4 Kodeksu rodzinnego i opiekuńczego ${ }^{17}$ (dalej: k.r.o.) dokonanie darowizny kosztem majątku wspólnego wymaga zgody obojga małżonków. Taka zgoda wystąpiła w rozpoznawanych sprawach. Z zawartej w dniu 25 lipca 2010 r. umowy darowizny wynika, że została ona zdziałana do majątku odrębnego obdarowanej (art. 33 pkt 2 k.r.o.), gdyż z umowy nie wynika, by darczyńcy postanowili inaczej. Jednakże chodzi tu o darowiznę pieniędzy, a nie darowiznę nieruchomości, gdyż ta nie była przedmiotem tej umowy. Przepis art. 893 k.c. wprost stanowi, że polecenie ma polegać na działaniu lub zaniechaniu, a więc także na klasycznym świadczeniu, o którym mowa w art. $353 \$ 2$ k.c. Darowizna jest umową konsensualną i jednostronną, a jej istotą jest zobowiązanie się do działania lub zaniechania (art. 353 $\$ 2$ k.c.), zawsze kosztem majątku darczyńcy. Podkreślenia wymaga też to, że z chwilą złożenia zgodnych oświadczeń woli przez strony umowy darowizny jej przedmiot wchodzi do majątku obdarowanego. Świadczenie z tytułu tej umowy może być dokonane również na rzecz osoby trzeciej, gdyż z treści art. $888 \$ 1$ k.c. nie wynika, by obdarowanym musiała być zawsze druga strona umowy. Poczucie wdzięczności czy nadzieja uzyskania korzyści nie mają znaczenia dla jej ważności. Z zawartej w rozpoznawanych przez NSA sprawach umowy darowizny nie wynika wprost przyczyna świadczenia darczyńcy, ale nie budzi wątpliwości, że była to umowa o podstawie świadczenia causa donandi. Świadczenie z umowy darowizny może być spełnione zarówno z chwilą zawarcia umowy, jak i w pewien czas po jej zawarciu, gdy strony tak postanowią, a także przed jej zawarciem, np. spłata, kosztem swego majątku, długu za inną osobę bez zawiadomienia jej o tym ${ }^{18}$. Jest tak ze względu na treść art. $356 \$ 2$ k.c. W realiach spraw rozpatrywanych przez NSA ważność umowy i wartość nabytych rzeczy nie budziły zastrzeżeń, co sąd wyraźnie wskazał. Należy tu ponadto wskazać, że w sprawach tych darczyńcy nałożyli na obdarowaną (drugą stronę umowy) obowiązek świadczenia na rzecz osoby trzeciej (męża obdarowanej), co w umowie nazwano poleceniem, a także obowiązek nabycia nieruchomości za 65000 zł. Naczelny Sąd Administracyjny przyjął zgodnie z treścią umowy, że było to polecenie, i w dodatku, że miało ono charakter zobowiązania naturalnego, co wydaje się wątpliwe. Jednakże to, czy było to polecenie, w szczególności co do wypłacenia przez obdarowaną kwoty 55000 zł mężowi, nie jest takie oczywiste. W wyroku

${ }^{17}$ Dz.U. z 2017 r., poz. 682.

${ }^{18}$ S. Rejman, Komentarz do art. 888 k.c., [w:] Kodeks cywilny. Komentarz. Ksiega trzecia - zobowiązania, red. Z. Resich, WP, Warszawa 1972, s. 1731. 
z dnia 21 marca 1973 r. (sygn. III CRN 40/73, OSNCP 1974, nr 2, poz. 26) Sąd Najwyższy (SN) stwierdził, iż „Mimo że kodeks cywilny nie przejął przepisu art. $354 \$ 2$ k.z., darczyńcy wolno obciążyć drugą stronę umowy darowizny (obdarowanego) obowiązkiem spełnienia oznaczonego świadczenia na rzeczy osoby trzeciej, przez co czyni on tę osobę wierzycielem obdarowanego". Podobnie we wcześniejszej uchwale z dnia 11 marca 1970 r. (sygn. III CZP 28/70, OSNC 1971, nr 10, poz. 171) Sąd Najwyższy przyjął pogląd, że „Obciążenie w umowie darowizny lub dożywocia nabywcy nieruchomości rolnej obowiązkiem zapłaty na rzecz osoby trzeciej określonej kwoty pieniężnej jest dopuszczalne”. W tym ostatnim przypadku pogląd ten SN wyprowadził z faktu, że „przepisy o dziedziczeniu gospodarstw rolnych, a wśród nich przepisy ograniczające możliwość obciążenia spadkobiercy gospodarstwa rolnego zapisami, mają jako przepisy ograniczające ustawowy krąg spadkobierców i ograniczające swobodę testowania spadkodawcy, charakter norm wyjątkowych, co oznacza, że nie powinny być interpretowane rozszerzająco. Oznacza to, że brak jest podstaw do twierdzenia, że wprowadzają one jakiekolwiek ograniczenia, które wyłączałyby lub utrudniały właścicielowi gospodarstwa rolnego dyspozycję tym gospodarstwem"19. W glosie do tej uchwały, częściowo krytycznej, L. Stecki ${ }^{20}$ trafnie wskazał, że zarówno pytanie prawne, jak i stan faktyczny nie uzasadniały rozważań Sądu Najwyższego w sprawie na tle przepisów o dziedziczeniu gospodarstw rolnych, skoro jej stan faktyczny odnosił się do umowy darowizny (dożywocia).

Jednakże w pytaniu prawnym nie pojawiło się zagadnienie darowizny z poleceniem. Rozpatrując tę sytuację, glosator trafnie dochodzi do wniosku, że mimo lakonicznego uzasadnienia Sąd Najwyższy trafnie wskazał, iż dokonanie w wyniku polecenia zapłaty określonej sumy pieniężnej kosztem otrzymanego nieodpłatnie przez obdarowanych gospodarstwa rolnego jest dopuszczalne w każdym przypadku, a więc niezależnie od tego, czy uprawniony z polecenia ma kwalifikacje do prowadzenia gospodarstwa rolnego, czy ich nie ma. Glosator ma tu rację, mimo że Sąd Najwyższy nie powołał się na przepis art. $354 \$ 2 \mathrm{k}$.z. nieprzyjęty do Kodeksu cywilnego ${ }^{21}$.

${ }^{19}$ Uzasadnienie uchwały SN z dnia 11 marca 1970 r., sygn. III CZP 28/70, OSNCP 1971, nr 10, poz. 71.

${ }^{20}$ Zob. L. Stecki, Glosa do uchwały SN z dnia 11 marca 1970 r., III CZP 28/70, NP 1972, nr 7-8, s. 1216-1222.

${ }^{21} \mathrm{Z}$ art. $354 \$ 2$ k.z. wynika, że „Darczyńca może obciążyć obdarowanego obowiązkiem spełnienia oznaczonego świadczenia”. 
Ta kwestia stała się zaś przedmiotem rozważań Sądu Najwyższego w przywoływanym już wyroku z dnia 21 marca 1973 r. (sygn. III CRN 40/73), w którym także SN dopuścił możliwość ustanowienia polecenia na korzyść osoby trzeciej. Jak pisze Sąd Najwyższy już na gruncie art. 893 i art. 894 $\$ 2$ k.c., to, że osoba trzecia, na rzecz której ustanowiono polecenie, nie jest wierzycielem i nie może we własnym interesie domagać się jego wypełnienia, jest istotą polecenia. Jednakże według sądu $\mathrm{z}$ faktu nieprzejęcia do Kodeksu cywilnego przepisu art. $354 \$ 2$ k.z. przewidującego tzw. darowiznę obciążliwą, zobowiązującą obdarowanego do świadczenia czegoś na rzecz osoby trzeciej, i z wprowadzenia przepisu art. 893 k.c., zezwalającego na dodanie do darowizny polecenia, nie można wyprowadzać wniosku, by obciążenie obdarowanego obowiązkiem wykonania oznaczonego świadczenia na rzecz oznaczonego wierzyciela było z mocy art. $58 \$ 1$ k.c. nieważne. Dalej Sąd Najwyższy stwierdza, że zarówno darowiznę obciążliwą, jak i darowiznę z poleceniem określa się tym samym mianem donatio cum modo, przy czym polecenie takie może być zastrzeżone na korzyść osoby trzeciej. Różnica między darowizną obciążliwą a darowizną z poleceniem polega na tym, że wykonania polecenia mogą żądać darczyńca i jego spadkobiercy (art. 894 k.c.), a nie osoba trzecia wskazana przez darczyńcę w umowie darowizny. Zauważyć tu tylko należy, że wyrażane są też poglądy, iż nawet wówczas, gdy w umowie obdarowany został zobowiązany, czy też sam się zobowiązał, do świadczenia na rzecz osoby trzeciej, to osoby te nie mogą żądać od obdarowanego, by wypełnił ciążące na nim zobowiązanie ${ }^{22}$. Sąd Najwyższy podkreśla, że także z art. $888 \$ 1$ k.c. wynika możliwość darowizny nie tylko na rzecz kontrahenta, lecz i osoby trzeciej. Przepis bowiem - jak zresztą przyjął też Naczelny Sąd Administracyjny w komentowanych wyrokach, nie wskazując jednak podstawy prawnej - nie stanowi, że obdarowanym może być wyłącznie strona umowy, co oznacza, że skoro całość świadczenia bezpłatnego może być przeznaczona na rzecz osoby trzeciej, to dopuszczalne będzie również postanowienie, iż część świadczenia darczyńca przeznacza swemu kontrahentowi, a część osobie trzeciej. Jest charakterystyczne, że powyższy wyrok Sądu Najwyższego, w kwestiach przedstawionych wyżej, spotkał się z trzema aprobującymi glosami ${ }^{23}$. Szczególnie interesujące są wywody L. Steckiego, który pisze, że „Polecenie nie jest

22 Zob. S. Grzybowski, Darowizna, [w:] System Prawa Cywilnego. Prawo zobowiązań - część szczegółowa, red. S. Grzybowski, Ossolineum, Wrocław 1976, s. 242.

${ }^{23}$ Zob. L. Stecki, Glosa do wyroku SN z dnia 21 marca 1973 r., CRN 40/73, NP 1975, nr 10-11, s. 1477-1483; H. Goik, Glosa do wyroku SN z dnia 21 marca 1973 r., III CRN 40/73, 
osobnym zobowiązaniem powstającym niejako niezależnie od darowizny. Obdarowany, godząc się na przyjęcie darowizny, staje się tym samym zobowiązanym do uczynienia zadość poleceniu darczyńcy. Nie warto - jak pisze - kruszyć kopii o to, czy polecenie i świadczenie to pojęcia identyczne, czy odrębne, a przeprowadzenie linii podziału między nimi nie jest ani łatwe, ani potrzebne. W praktyce bowiem treść obowiązku obdarowanego jest często taka sama, jak w wypadku istnienia zwykłego zobowiązania”. Zwraca przy tym uwage na trudności dowodowe związane $\mathrm{z}$ ustaleniem rzeczywistej woli stron w takim przypadku, a także konieczność dokładnej analizy treści umowy. W głosowanych wyrokach takich ustaleń brak, albowiem zarówno sąd pierwszej instancji, jak i Naczelny Sąd Administracyjny przyjęły zgodnie, że stan faktyczny sprawy jest prosty i nie budzi wątpliwości. Glosator powyższy dalej pisze, że „stosowanie takich zwrotów jak «nałożenie obowiązku działania lub zaniechania» bądź «obciążenie obowiązkiem» spełnienia świadczenia zdaje się nie czynić zadość niezbędnym rygorom legislacyjnym w odniesieniu do dwustronnych czynności prawnych, jakimi są umowy, w których jedna ze stron zobowiązuje się do świadczenia, a druga wyraża swą zgodę na to lub zobowiązuje się także do oddzielnego świadczenia"24. Dlatego, jak pisze, "Skoro Sąd Najwyższy przyjął, że w sprawie chodziło o pactum in favorem tertii, to konsekwentnie wypadało stwierdzić, że pomimo nieprzyjęcia do kodeksu cywilnego przepisu art. $354 \$ 2$ k.z. strony umowy darowizny mogą jednocześnie umówić się co do tego, że obdarowany jest zobowiązany do spełnienia oznaczonego świadczenia na rzecz osoby trzeciej, jako jego wierzyciela" ${ }^{25}$. Wówczas chodziłoby nie o darowiznę z poleceniem, lecz o umowę mieszaną, w której obdarowany zobowiązał się do spełnienia na rzecz osoby trzeciej jako wierzyciela określonego świadczenia. „W takiej umowie mieszanej darowizna obejmie tylko tę część świadczenia, którą darczyńca zobowiązuje się spełnić bezpłatnie kosztem swego majątku. Świadczeniem uzyskanym przez obdarowanego pod tytułem nieodpłatnym będzie tylko to, co pozostało po oddzieleniu wartości, jaką w ramach przyjętego przez siebie obowiązku wydał osobie trzeciej”. Wprawdzie A. Policiński w glosie do omawianego wyroku kwestionuje dopuszczalność zobowiązania się obdarowanego do oddzielnego świadczenia na rzecz osoby trzeciej, to

OSP 1974, nr 11, poz. 230; A. Policiński, Glosa do wyroku SN z dnia 21 marca 1973 r., III CRN 40/73, OSP 1974, nr 11, poz. 230.

${ }^{24}$ L. Stecki, Glosa do wyroku..., s. 1479.

${ }^{25}$ Ibidem. 
przecież, jak trafnie pisze L. Stecki, „Powoływanie do bytu dwóch (lub więcej) zobowiązań mocą jednej umowy jest zjawiskiem społeczno-prawnym mającym już swoją historię i [...] dopuszczalność takiego konstruowania treści konkretnej umowy nie była dotąd kwestionowana". To oznacza, że treścią jednej umowy może być darowizna i sprzedaż czy sprzedaż i zamiana. Obok darowizny z poleceniem może więc istnieć darowizna połączona $\mathrm{z}$ umową o świadczenie na rzecz osoby trzeciej. Powracając do przyjętych przez Naczelny Sąd Administracyjny ustaleń, należy zwrócić uwagę na to, że nie przywiązał on należytej wagi do treści $\$ 3$ ust. 1 pkt 1 i 2 umowy darowizny. Z wprowadzenia zawartego w $\$ 3$ umowy wynika, że „darczyńcy nakładają na obdarowaną obowiązek przeznaczenia przedmiotu darowizny [...] na zakup nieruchomości, przy czym jego realizacja ma nastąpić w następujący sposób:

- część sumy pieniężnej [...] zostanie przekazana przez obdarowaną sprzedającej nieruchomość,

- pozostała część sumy pieniężnej stanowiącej przedmiot darowizny [...] zostanie przez obdarowaną przekazana mężowi obdarowanej”.

$\mathrm{W} \S 3$ ust. 2 umowy wskazano, że postanowienia zawarte w ust. 1 są poleceniem w rozumieniu art. 893 k.c. Rzecz jednak w tym, że „u podstaw ustawowej konstrukcji polecenia legł zamiar stworzenia szerszej niż świadczenie w postaci obowiązku strony stosunku zobowiązaniowego. Ustawodawca bowiem stosunkowo ogólnie reguluje przedmiot polecenia, w szczególności obowiązek taki nie musi przybierać postaci świadczenia. Polecenie może mieć na względzie interes majątkowy i osobisty; może dotyczyć sytuacji obdarowanego, ale także osób trzecich bezpośrednio lub poprzez realizację celów społecznych ogólniej sformułowanych. [...] Nie zawsze cele te mieszczą się w klasycznej formule świadczenia" ${ }^{26}$. Nałożenie na obdarowanego obowiązku świadczenia na rzecz osoby trzeciej (polecenie z art. 893 k.c.) tylko wówczas nie pozbawia umowy cech nieodpłatności, gdy nie przekreśla istoty darowizny wyrażającej się w przysporzeniu majątku obdarowanego kosztem majątku darczyńcy ${ }^{27}$. Powyższe, a także treść art. $353 \$ 2$ k.c. (świadczenie może polegać na działaniu lub zaniechaniu) będącego w części treścią art. 893 k.c., wskazuje, że polecenie może polegać także na nałożeniu obowiązku świadczenia.

${ }^{26}$ J. Jezioro, Komentarz do art. 893 k.c., [w:] Kodeks cywilny. Komentarz, t. 2, red. E. Gniewek, Komentarz do art. 535-1088, C.H. Beck, Warszawa 2004, s. 650.

${ }^{27}$ Wyrok Sądu Apelacyjnego w Katowicach z dnia 3 lutego 1995 r., sygn. I ACa 752/94, OSA 1997, nr 3, poz. 20. 
Z brzmienia $\$ 3$ ust. 1 pkt 1 i 2 umowy darowizny wynika, że darczyńcy nałożyli na obdarowaną obowiązek przekazania sumy darowizny dwóm osobom: sprzedającej nieruchomość i mężowi obdarowanej. W przypadku osoby sprzedającej nie jest to świadczenie (wierzytelność), albowiem sprzedająca na podstawie tego zapisu nie byłaby w stanie (brak wymaganej formy aktu notarialnego) dochodzić zawarcia umowy sprzedaży i zapłaty ceny (art. 64 k.c. w zw. z art. $1047 \$ 1$ i 2 k.p.c.). Jest to więc klasyczne polecenie, które nie kreuje wierzytelności (świadczenia) po stronie sprzedającej nieruchomość. W drugim zaś przypadku jest to niewątpliwie wykreowanie zobowiązania: darczyńcy nakładają na obdarowaną obowiązek świadczenia i mąż obdarowanej występuje tu jako wierzyciel (art. $393 \$ 1$ k.c.). Powstaje zatem zasadnicze pytanie, czy i ewentualnie jakie konsekwencje takiego rozróżnienia tych instytucji prawnych powstają na gruncie podatku od spadków i darowizn.

5. Aby odpowiedzieć na to pytanie, należy najpierw rozstrzygnąć, czy mamy tu do czynienia z klasyczną umową nazwaną darowizny czy z umową mieszaną, jak przyjmuje L. Stecki w omówionej wyżej glosie. Jeżeli nawet przyjąć, że jest to umowa mieszana, to jednak jej nieodpłatny charakter nie budzi wątpliwości. Przyczyną jej zawarcia, jak wynika z $\$ 1$ ust. 4 umowy, było „przekazanie obdarowanej środków pieniężnych na nabycie nieruchomości” do jej majątku odrębnego, a jej celem nałożenie przez darczyńców na obdarowaną obowiązku nabycia nieruchomości. Zamiarem zaś obdarowanej było nabyć, wraz z mężem, nieruchomość bez wskazania, czy nabycie miało nastąpić do majątku wspólnego czy na współwłasność. Okoliczności te nie pozbawiają umowy darowizny jej nieodpłatnego charakteru. Tego charakteru nie pozbawia tej umowy także zobowiązanie obdarowanej do świadczenia na rzecz męża. Powstaje jednak zasadnicze pytanie o wartość przedmiotu darowizny, a mianowicie, czy darczyńcy świadczyli obdarowanej kwoty po $60000 \mathrm{zł}$ czy kwotę 65000 zł.

Naczelny Sąd Administracyjny tej kwestii nie rozstrzygał przede wszystkim dlatego, że nie mógł. Miał bowiem do rozpoznania tylko skargę kasacyjną skarżącej (obdarowanej), gdyby więc przyjąć koncepcję drugą, to orzekałby na niekorzyść skarżącej. Oczywiście, mógł też skargę kasacyjną na powyższej przesłance oddalić.

Należy jednak wyrazić pogląd, że w umowie darowizny, o której mowa, wartość przedmiotu darowizny obejmuje tylko tę część świadczenia, którą darczyńca zobowiązuje się spełnić bezpłatnie kosztem swego majątku. Świadczeniem uzyskanym przez obdarowaną pod tytułem darmym będzie 
więc tylko to, co powstało po oddzieleniu wartości, jaką w ramach przyjętego na siebie obowiązku wydała osobie trzeciej. Z umowy wprost wynika, że darczyńcy nałożyli na obdarowaną obowiązek świadczenia 55000 zł na rzecz męża. To, że darczyńcy, jak wynika z wprowadzenia do $\$ 3$ umowy, przenieśli na obdarowaną tytułem darowizny kwotę 120000 zł, nie oznaczało, że taka kwota była przedmiotem świadczenia $z$ umowy. Zgodnie $\mathrm{z}$ art. $888 \$ 1$ k.c. przedmiotem umowy jest świadczenie na rzecz obdarowanego. A wartość tego świadczenia na rzecz obdarowanej wynosi 65000 zł (czyli $2 \times 32500$ zł). Z art. 7 ust. 1 i 2 u.p.s.d. wynika, że „Podstawę opodatkowania stanowi wartość nabytych rzeczy i praw majątkowych po potrąceniu długów i ciężarów (czysta wartość), ustalona według stanu rzeczy i praw majątkowych $w$ dniu nabycia i cen rynkowych $\mathrm{z}$ dnia powstania obowiązku podatkowego [...]. Jeżeli [...] obdarowany [...] został obciążony obowiązkiem wykonania polecenia albo zapisu zwykłego, wartość obciążenia $\mathrm{z}$ tego tytułu stanowi ciężar [...] darowizny, a w przypadku polecenia, jeżeli zostało wykonane”. Wartością nabytych rzeczy - tu: pieniędzy, jak przedstawiono wyżej, była kwota 65000 zł, ale ciężarem darowizny wynikającym z polecenia był obowiązek nabycia nieruchomości za kwotę 65000 zł, którą obdarowana miała obowiązek przekazania sprzedającej (czyli $2 \times 32500 \mathrm{zł}$ ). Oznaczało to, że w istocie rzeczy nie wystąpiła podstawa opodatkowania, a tym samym i zobowiązanie podatkowe wyniosło 0 zł. Taki pogląd wyraził Naczelny Sąd Administracyjny i był to pogląd trafny. Argumentacja sądu jest tu jednak odmienna i zbudowana na tym, że przedmiotem darowizny była kwota $120000 \mathrm{zl}$, a wartość polecenia jako ciężar darowizny wynosiła także 120000 zł.

Postawić też należy pytanie o zagadnienie konsekwencji podatkowych polecenia i świadczenia (wierzytelności). Otóż w pierwszym przypadku wykonanie polecenia podlega podatkowi od spadków i darowizn. Obdarowana $z$ tytułu polecenia darczyńcy powinna zatem być obciążona podatkiem od spadków i darowizn (art. 1 ust. 1 pkt 2 u.p.s.d.), z tym że w przypadku złożenia w terminie zgłoszenia zwolnienia podatkowego (art. $4 \mathrm{a}$ ust. 1 pkt $1 \mathrm{w}$ zw. $\mathrm{z}$ art. 6 ust. 1 pkt 5 u.p.s.d.) nabycie to nie podlegałoby opodatkowaniu. W przypadku zaś niezłożenia zgłoszenia, a tym samym niespełnienia warunków do zwolnienia podatkowego $\mathrm{z}$ art. 4a ust. 1 pkt 1 u.p.s.d., nabycie podlegałoby opodatkowaniu tak jak u podatników I grupy podatkowej. Polecenie zostało ustanowione przez rodziców (art. 4a ust. 3 w zw. z art. 6 ust. 1 pkt 5, w zw. z art. 14 ust. 3 pkt 1 i art. 9 ust. 1 pkt 1 u.p.s.d.), co oznaczałoby, że kwota wolna od podatku 
wyniosłaby 9637 zł w stosunku do każdego nabycia od każdego z rodziców. Tym samym podstawa opodatkowania w każdym z tych przypadków wynosiłaby $65000: 2=32500-9637$ zł = 22863 zł. Natomiast mąż obdarowanej, który otrzymał wierzytelność w kwocie 55000 zł, podlegałby również podatkowi od spadków i darowizn, albowiem darowizną może być też świadczenie nieodpłatne na rzecz osoby trzeciej (art. 393 $\$ 1$ k.c.). Niewątpliwe jest przecież, że darczyńca czynił to świadczenie kosztem swojego majątku (art. $888 \$ 1$ k.c.). Jednakże zięć nie jest uprawniony do skorzystania ze zwolnienia podatkowego $\mathrm{z}$ art. 4 a ust. 1 u.p.s.d. Podlegałby on zatem opodatkowaniu tak jak podatnicy grupy I i skorzystałby ze zwolnienia kwoty stanowiącej minimum podatkowe, czyli $2 \times$ po 9637 zł. Podstawa opodatkowania w jego przypadku wynosiłaby: $55000: 2=27500-9647=17863 \mathrm{zl}(\times 2)$.

Z tych względów wyroki Naczelnego Sądu Administracyjnego należy określić jako trafne, jednak przy wadliwej argumentacji prawnej.

\section{BIBLIOGRAFIA}

Alexy R., Balancing, Constitutional Review and Representation, Oxford University Press - New York University School of Law 2005, T-CON, vol. 3, no. 4.

Alexy R., Theory of Constitutional Rights, Oxford University Press, New York 2002.

Bartosiewicz A., Kubacki A., Glosa do uchwaty 7 sędziów NSA z dnia 28 maja 2007 r., I FPS 5/06, „Glosa” 2008, $\mathrm{nr} 2$.

Brzeziński B., Podstawy wykładni prawa podatkowego, ODDK, Gdańsk 2008.

Brzeziński B., Nykiel W., Zasady ogólne prawa podatkowego, „Przegląd Podatkowy” 2002, nr 3. Brzeziński B., Zirk-Sadowski M., Specyfika wykładni prawa podatkowego, [w:] Zagadnienia ogólne prawa podatkowego, red. W. Nykiel, M. Wilk, CDISP, Łódź 2014.

Darowizna $z$ poleceniem bez podatku - przełomowy wyrok NSA, „Rzeczpospolita” 7.06.2018.

Gniewek E., Komentarz do art. 45 [w:] Kodeks cywilny. Komentarz, t. 1, red. E. Gniewek, C.H. Beck, Warszawa 2004.

Goik H., Glosa do wyroku SN z dnia 21 marca 1973 r., III CRN 40/73, OSP 1974, nr 11, poz. 230.

Grzybowski S., Darowizna, [w:] System Prawa Cywilnego. Prawo zobowiązań - część szczegółowa, red. S. Grzybowski, Ossolineum, Wrocław 1976.

Ignatowicz J., Komentarz do art. 45 [w:] Kodeks cywilny. Komentarz, t. 1, red. Z. Rosiak, WP, Warszawa 1972.

Jezioro J., Komentarz do art. 893 k.c., [w:] Kodeks cywilny. Komentarz, t. 2, red. E. Gniewek, Komentarz do art. 535-1088, C.H. Beck, Warszawa 2004.

Katner W.J., Komentarz do art. 45 k.c. lit. E, [w:] Kodeks cywilny. Komentarz. Czesść ogólna, red. P. Księżak, M. Pyziak-Szafnicka, LEX/el. Warszawa 2014. 
Koniec podatku od spadków i darowizn. Fiskus straci wpływ z podatku od spadków i darowizn, „Dziennik Gazeta Prawna” 7.06.2018.

Korzycka-Zirk M., Teorie zasad prawa a zasada proporcjonalności, LexisNexis, Warszawa 2012. Policiński A., Glosa do wyroku SN z dnia 21 marca 1973 r., III CRN 40/73, OSP 1974, nr 11, poz. 230.

Projekt przepisów ogólnych Ordynacji podatkowej, opracowany przez zespół roboczy Centrum Dokumentacji i Studiów Podatkowych w Łodzi w składzie: prof. dr hab. B. Brzeziński, prof. dr hab. W Chróścielewski, dr H. Dzwonkowski, dr hab. M. Kalinowski, dr M. Masternak, prof. dr hab. W. Nykiel (przewodniczacy) i dr A. Olesińska, „Kwartalnik Prawa Podatkowego" 2001, nr 3-4.

Rejman S., Komentarz do art. 888 k.c., [w:] Kodeks cywilny. Komentarz. Ksiega trzecia - zobowiazania, red. Z. Resich, WP, Warszawa 1972.

Stecki L., Glosa do uchwały SN z dnia 11 marca 1970 r., III CZP 28/70, NP 1972, nr 7-8.

Stecki L., Glosa do wyroku SN z dnia 21 marca 1973 r., CRN 40/73, NP 1975, nr 10-11.

Tuleja P., Zasady konstytucyjne, [w:] Konstytucjonalizacja zasad i instytucji ustrojowych, red. P. Sarnecki, Wydawnictwo Sejmowe, Warszawa 1997.

Zieliński M., Konstytucyjne zasady prawa, [w:] Charakter i struktura norm konstytucji, red. J. Trzciński, Wydawnictwo Sejmowe, Warszawa 1997.

\section{Gloss to the Decisions of the Supreme Administrative Court OF 6 JUNE 2018, REF. NO. II FSK 1525/16 AND II FSK 1526/16}

Summary. A donation agreement may be burdened with an instruction (Art. 893 of the Civil Code). The nature of the instruction is not uniform because its content also includes the possibility of establishing a commitment to provide a certain monetary amount pursuant to Art. $393 \$ 1$ of the Civil Code. In this case, the value of the donation should be the difference between the amount of donation obtained by the recipient and the amount of the benefit to a third party (Art. $888 \$ 1$ in conjunction with Art. 893 of the Civil Code). A donor's instruction for the recipient is a burden on the donation and is therefore deductible from its value. Meanwhile, a free of charge benefit performed by the donor towards the said third party is not burdened. However, the person receiving the benefit would be subject to the inheritance and donation tax on general terms (Art. 1 par. 1 point 2, Art. 6 par. 1 point 4, Art. 9 par. 1 point 1 and Art. 14 par. 3 point 1 of the Act on inheritance and donation tax). The value of the said benefit is not a debt or burden for the beneficiary, as it was performed at the expense of the donor's assets, not the beneficiary's (Art. $888 \$ 1$ of the Civil Code, Art. 7 par. 1 and 2 Act on inheritance and donation tax).

Keywords: donation, instruction of a donor, the benefit to a third party, debts and burdens of a donation and instruction of a donor 